ERRATUM:

ORIGINAL PAPER

\title{
Current approach for urinary system stone disease in pregnant women
}

Orcun Celik, Hakan Türk, Rahmi Gokhan Ekin, Ozgur Cakmak, Salih Budak, Mehmet Zeynel Keskin, Guner Yildiz, Yusuf Ozlem Ilbey

Urology Department, Tepecik Educational and Research Hospital, İzmir, Turkey.

Due to a technical error, Dr. Salih Budak was omitted from the author list of this article.

The correct author details and order appear above.

Archivio Italiano di Urologia e Andrologia

DOI: 10.4081/aiua.2015.4.280 